\title{
Human Resource Accounting
}

\author{
Masoud Ghorban Hosseini \\ PhD student, Department of Management, Saveh branch, Islamic Azad University, Saveh, Iran
}

\begin{abstract}
Human Resource Accounting (HRA) involves accounting for expenditures related to Human resources as assets as opposed to traditional accounting which treats these costs as Expenses that reduce profit. Accountants have recognized the value of human assets for at least 70 years. Human resource accounting is not a new issue in conomics. Economists consider human capital as a production factor, and they explore different ways of measuring in investment in education, health, and other areas.

Human resource accounting (HRA) is an attempt to identify, quantify and report investment made in Human resources of an organization that are not presently accounted for under conventional accounting practice. The concept of "investment" in employees; the human capital of the organization, push forward a view that one is looking for a profit to be gained from the investment and therefore the focus is on the development of employees for a specific purpose to gain. Investment in professional training is often treated as an industrial relation activity, and not as an essential investment decision like for the plant or technology. When we consider human assets accounting, the under lined idea is, we are considering the human inventory stock of a company incorporated available to the organization to perform the activities. The concept of human resource accounting can be basically examined from two dimensions:(I) the investment in human resources; and (ii) the value of human resources. The expenditure incurred for creating, increasing, and updating the human resource quality is known as investment in human resources. Such investment yields fruitful results like higher productivity and higher income to the organization.
\end{abstract}

Keywords: Human Resource, Costing and Accounting, , Intangible Assets, Intellectual Capital, Performance improvement, Human Resource Management, accounting Concepts

\section{Introduction}

The era of industry and industrial net thought has been expired and now it is economic period based upon knowledge and human capitals in knowledge-oriented organization have found special role and importance and management on human capitals and knowledgeable personnel's in today organizations has been changed to secret of the success. Therefore human capital is the only saving that can during change of itself, change other savings of production or adjust it and provide a base for innovation which in extended level results to economic growth.

In Management modern events, role of manager is changed from command role and control to role of training and two efficiency and effectiveness categories are focused by managers and should be considered that in today economy implicit and intangible properties together with explicit (tangible) properties determine the validity of organization.

\section{Trend of Accounting Evolutions:}

Accountants from the fist of accounting birth have passed three phases: 1) Listing Accounting, 2) Financial Accounting, 3) Management Account; and future challenge of accounting is fourth phase of it or "Social-economic Accounting" one of categories of which is Human Resource Accounting.

\section{Human Resources Accounting Definition:}

According to definition US Accounting Association is process of realization and measurement of information about human resources and reporting these information's to interested and beneficiary individual. In deed Human Resource Accounting is converting quality and subjective conception of human resources in scale of quantity and objective by using of accounting knowledge and deals with three important sections about human resources including: Identification of its quantity and quality, its evaluation and measurement of economic value and financial reporting proportionate to it.

\section{Necessity and Human Resources Accounting Goals}

Representing Human Resources Economic Value Information as the main Property of Organization in Information Revolution of these Era Most organizations can represent exact information's about their tangible properties such as land, building, machineries and equipment. But usually they never have any official record of their intangible properties such as trademarks, research, development and human resources expenses which 
have ever-increasing value for organization. Therefore, lack of information about economic value, human properties of organization or expenses made for Educating of specialists and scale of lost costs is from weak point of present account system (Beattie V., Brandt. R, and Fernley, S. 1999).

\section{Calculation of Organization Investment Scale in Human Resources}

Most of organizations consume main amounts for training programs of personnel without evaluating yield of mentioned investment and it results exactly. And even in case of non-ability of providing cost, stop training program. Therefore with regard to necessity of separation of charges made in relation with human resources from other expenses of trade unit, we should consider distinct between current and capital expenses of human resources. Because these information capable management to make decision on the basis of interest and capital expenses (Martikanien, T 2003).

\section{Increasing Efficiency of Human Resource Management}

Human resources accounting is the reconciliation of two area of accounting and human resources management. Application of methods and accounting concepts and using of technique and model of measurement can have deep effect in manner of administration of organization individuals and enable personnel to successful partnership in advancement of organization goals.

\section{Evaluation of Human Resources of an Organization in this regard that it has been preserved declined ore improved.} Methods of Human Resources Value Measurement:

Human resources accounting can be investigated through two methods bellow:

\section{Human Resources Finding Costs:}

An accountant system of human resources in the first phase needs to recognition expenses are occurred in relation with human resources which should be separated from other costs of trade unit.

Applied approaches and methods should consider distinction between capital and current section of costs.

Finding costs of Human resources is formed of two sections bellow:

1-1- Initiate Costs: Are all funds are consumed in providing and educating of human resources such as selection and employment and in-service training and applicable and specialty training for achieving skill.

2-1- Replacement Costs: Replacement costs of personnel who at the present are working in organization and are included:

A) Position or job replacement Costs: These are costs that are for replacement of an individual in an organization with a person who can represent similar services that are included providing expenses, educating or training and resigning. Resigning cost is including all resigning reward expense, remaining post without tenure and balance before resigning.

B) All personnel expenses including rewards (cash and non-cash), facilities (tools, furniture, expenditures and necessary equipments for personnel welfare, healthcare, costs for consulting and conversation, paid salary and wages and other payments such as insurance.

\section{To Value Human Resources}

Human resources accounting more than finding expense are needed to value. Conception of human resources value is based upon value theory in general economy. With regard to this point that human is able to creating future potential benefits, we can define human value as other resources as present value of anticipated future services. Therefore, individual value is present value of a collection of services which it is anticipated that individual creates during his/her services in organization. Some groups have failed this theory and believe human is higher than evaluation and indeed is invaluable. In respect to researchers' theory for measurement of human resources there are two basis phases: This means that at first we should determine human resources conception in a non-monetary or qualitative expression to can represent it in a monetary expression for indicating in balncesheet of organization.

\section{Human Capital Measurement Criteria:}

- Financial criteria such as sale and financial operation.

- Criteria of yielding produced good and services provided for customer, number of faults, customer satisfaction and quality of services.

- Time delay criteria, absence.

According to a research was made in 2004 on valuation of human resources in England criteria bellow were identified which in more than $50 \%$ of organizations are used for valuating of human resources: 
Human resource accounting

\begin{tabular}{|l|l|}
\hline Human Capital Activities & Possible Measurement \\
\hline Applying new force & $\begin{array}{l}\text { Cost, time, quantity, quality, compatibility with } \\
\text { strategic standards }\end{array}$ \\
\hline Dismissal & Reasons of leaving job, rate of leaving services \\
\hline Reward/service consumption & $\begin{array}{l}\text { Level of payments, differences, justice evaluation, } \\
\text { customer satisfaction, satisfaction of personnel }\end{array}$ \\
\hline Competences/Training & $\begin{array}{l}\text { Measurement of competences, skills, competences } \\
\text { distance and investment in training }\end{array}$ \\
\hline Human resources diagram & $\begin{array}{l}\text { Age, rate of promotion, partnership in knowledge } \\
\text { management activities, variety, conducting, } \\
\text { organizational commitment. }\end{array}$ \\
\hline
\end{tabular}

\section{Challenges of Human Resources Valuating:}

Supporters of modern management have classified national wealth in four categories: Huan, material, machineries and money and have named labor and human terms, human resources. But we should acknowledge that human resources is not only number of individuals who are working in an organization, but it is a thing beyond of counting individuals. Human resources is considered as collection of knowledge, skills, creative abilities, talents and attitudes of workforce of an organization that indeed is whole inert capabilities, gained knowledge and skills of personnel. Expense of human resources easily is reflexed as profit and loss. But, human resources worth has never had place in balance sheet and main problem exactly is lack of a simple formula for execution of it. Gathering human resource information and lack of suitable understanding of these information's, has challenged reporting o human resources and quality of its information (Ezzamel, M. and Mar-Molinero, C. 1990).

\section{Intellectual Capital:}

Intellectual capital of a company is: knowledge, organizational technology, experience, and relation of customer and professional skills that holds it in market in computational position and is classified in three categories bellow:

1- Human capital: Group capability take part in taking best solutions and selection of the best individuals.

2- Structural Capital: Organizational capabilities of company in meeting market needs.

3- Customer Capital: Relation of organization with network of related companies and scale of their satisfaction to company and loyalty to them.

The main value of some goods also in today world is taken from taught capital and main part of goods price are formed by these costs. Cost value of material of a mobile phone receiver without considering its production technology is very few, but share of used thought technology is determinant of main share of its value. Therefore, measurement of intellectual capital can be made in two forms and in frame of two criteria:

1. Direct Criteria: This method is for measurement of intellectual capital on the basis conception of Return on Assets (ROA) according to ration of return on tax for a period of 3 to 5 years. Then this average is divided to average of tangible assets of the company during the same period. Interest to resulted assets is compared with average of industry of company to calculation of difference. Then this additional ROA is multiple tangible assets of company to annual additional average is gained. This amount divided to capital of company costs would be indicating of intellectual capital value.

(Capital company expense/average of company assets) $\div$ (Industry ROA-Company ROA)- Intellectual Capital (IC)

As it is clarified, achieved amount is proportionate to rate of company assets and this is the same anticipated intellectual capital, additional value which company gains in addition of its asset value.

2. Indirect Criteria: This is the purchaser who determines and defines value not supplier. Therefore what the market says about company is valuable. In amplest condition we can say that intellectual capital is equal to difference of market value of company and its book value and this value is called company added value of market.

For example market value of Microsoft Company is 412 billion dollars and total value of physical assets such as building, equipments, furniture's and factures is equal to 24 billion dollars.

From where the amount of 388 billion dollars difference has come and what is indicated by this amount? By courage we can say that this addition is value of intellectual thought which is hidden in inter-layers of company in form of organizational relation specially, human resource. 

XI. Some Methods of Valuing Human Resources:
1- Economic value (present value)
4- Model of random reward valuing
5- Bid theory
6- Historical cost value

2- $\quad$ Replacement value

3- Value co-efficient

\section{Human Resources Reporting:}

Main reason for evaluation of human resources assets and reporting of investment is there in human resources asset:

1. Providing information's relied to financial situation such as financial statements for awareness of investors, personnel and lenders.

2. Determining join of capital and work in organization operation.

3. Providing a base on the basis of economic motivations more for administrating organization and providing extended information's for performance of personnel tasks.

Decreasing investment on human resources may cause increasing of short term interest, but is a threat for profitability of organization in long term. The minimum advantage of using human resource accounting is availability of these information's for investors and it could be reported in four methods as bellow:

A) In report of Board of Director to General Assembly of Shareholders: Report of board of director to general assembly of shareholders mostly is including information's about expenses in relation with human resources which may be significant or even relatively more important that expenses which has made for tangible assets. As an initiate action about manner of operation of human assets account, board of directors may report made expenses for training of its personnel separately.

This types of information helps to investors and financial analyzers to evaluated scale of management attention to human resources development as a crucial factor for guarantee of profitability of company in long term.

B) Report of Intangible Assets: This method is suggested by Arthur Anderson Auditing Institute. This institute suggests that main amounts which are consumed for intangible assts including human resources, be reported separately on financial statements. That is the companies which bear huge expenses in relation with intangible assets, specially the companies which by sever dependent to technology have invested for their personnel or though merging and buying shares and paying large amounts for goodwill of their existent trade activities are growing, should provide a list of their intangible assets which indicates expenses paid for various intangible assets in current period and also last periods.

Among main restriction of this method is that balance sheet is misleader. Since, company assets value is represented less than reality. Measurement of profit or loss also has been defined, because all expenses related to human assets in the period have occurred are considered current expense and thus measurement of investment yield also would be defined.

C) Non Audited Financial Statements: Companies can represent and stipulate a collection of financial statements which is consisted of investment in human assets according to suggested methods of human resources accounting, as completion of information together with annual financial statements which mentioned financial statements should be investigated separate from main financial statements that are issued and provided according to accepted principles of accounting.

D) Providing in Basic Financial Statement: This method of investment in human assets is considered as long term asset and in anticipated useful life time of would be depreciated. However this practice about investments in human resources is not usual and common, but some institutes and companies such as air lines, electronic industries and sport and professional clubs which main part of their capitals is formed of human resources, apply this method (Foster, G. 1986).

\section{Which Expenses should be Considered Capital Expenses?}

This subject indeed is class fiction of human expenses as current and capital expenses. Main criteria for determining that what expenses should be considered current and what expenses capital or asset, depends on potential possibility of future services. However intangible assets have us elf and unlimited life, but in respect of accounting should be depreciated according to estimated useful life (Martikainen T., Perttunen J. and yeliOlli, P. 2000). Main aim of depreciation of human assets is compatibility of use of assets which benefits resulted from it. Usually this is named in accounting compatibility of expenses with incomes. Life of service of some human assets should be equal to anticipated transfer period of individual in organization. Service life of some others should be considered equal to a period that it is anticipated that individual occupies a specified position in an organization. Service life of some others should be a function of anticipated situation of technology. For example expenses of attraction and employment of individuals in organization be determined proportionate to the period which is anticipated the individuals would be in employment of company. 
However depreciation is main method of allocating human assets to costs, in some conditions and situations it is necessary to human assets account be adjusted. For example human assets because of desertion of employees by change in estimations of service periods, adjusted or removed from accounts. Undercoated balance of human asset account should be considered as loss of a period that change has occurred on it. One aspect of human resources which creates external reporting problems is probability of employees desertion (Martikanien, $\mathrm{T}$. 2003) Some organization have employment contract with their employees which restricts their transfer. But it is evident that humans are not under ownership of organization and main question of accounting also arises from where that how this problem could be solved by considering a reserve for anticipated costs of desertion.

\section{Conclusion:}

Promotion of human capital and its effect on different aspects of organization operation and in more extended level on economic and social development is not hidden for everybody. Promotion of this capital is including a collection of competences for Appling knowledge and skill for achieving to results of programs. Competences are embracing of features such is creativity, flexibility, capability of conducting, solving problem and making creative relation with others, job making and complex skill such as knowledge of manner of learning. Effort for measurement of activities relied to establishment of human capitals requires using of relied and liable tools and instruments. By using of human resources accounting we can evaluate suggested investment on human resources on the basis of cost finding methods and by using of historical cost value models with replacement model, measure our human resources and declared in accounting and management and reports and basic financial statements. Without doubt in today growing world and knowledge-based attention to human resources as an axe for development and recognition and measurement systems of this important and valuable resource is of necessities and role of managers and accountants as organizational decision maker of this field would be more strong and more sensible.

\section{References}

[1]. Beattie V., Brandt. R, and Fernley, S. (1999). Perceptions of Auditor Independence: UK Evidence, Journal of International Accounting. Auditing \& Taxation, 8(1), 67-107.

[2]. Berryman R.G. (1978). Auditor Independence: It’s Historical Development and Some [2] Proposals for Research. In S.B Loeb, Ed. Ethics in Accounting Profession, New York: John Wiley \& Sons, 141-158

[3]. Ezzamel, M. and Mar-Molinero, C. (1990). The Distributional Properties of Financial Ratios in UK Manufacturing Companies. Journal of Business Finance and Accounting, 17(1), 1-26

[4]. Horrigan, J.O. (1983). Methodological Implications of NonNormality Distributed Financial Ratios: A Comment. Journal of Business Finance and Accenting, 10(4), 683-689.

[5]. Foster, G. (1986). Financial Statement Analysis. Englewood Cliffs: Prentice-Hall. Frecka, T. J. and Hopwood, W.S. (1983). The Effects of Outlines on the Cross-sectional Distributional Properties of Financial Ratios. The Accounting Review, LVIII(1), 115 128

[6]. Martikainen T., Perttunen J. and yeli-Olli, P. (2000). Financial Ratio Distribution Irregularities: Implications for Ratio Classification, European Journal of Operational Research, 80(1), 34-44

[7]. Martikanien, T. (2003). Time-Series Distributional Properties of Financial Ratios: Empirical Evidence from Finnish Listed Firms. European Journal of Operational Research, 58(3), 344-355 